\title{
ANTINEOPLASTIC EFFECTS OF ERUFOSINE ON GRAFFI MYELOID TUMOUR IN HAMSTERS
}

\author{
A. K. GEORGIEVA ${ }^{1}$, R. A. TOSHKOVA ${ }^{1}$, K. S. TODOROVA ${ }^{1} \&$ R. D. TZONEVA ${ }^{2}$ \\ ${ }^{1}$ Institute of Experimental Morphology, Pathology and Anthropology with Museum, \\ Bulgarian Academy of Sciences, Sofia, Bulgaria; ${ }^{2}$ Institute of Biophysics and \\ Biomedical Engineering, Bulgarian Academy of Sciences, Sofia, Bulgaria
}

\section{Summary}

Georgieva, A. K., R. A. Toshkova, K. S. Todorova \& R. D. Tzoneva, 2021. Antineoplastic effects of erufosine on Graffi myeloid tumour in hamsters. Bulg. J. Vet. Med., 24, No 3, 442-449.

Cancer has become one of the most significant health challenges for both human and veterinary medicine. The present study examined the antineoplastic and antimetastatic activity of the novel membrane-targeting anticancer agent erufosine. The antitumour effects of erufosine on Graffi virusinduced experimental myeloid tumour in hamsters was assessed by histopathological methods and evaluation of some biometric parameters of tumour growth. Two schemes of experimental antitumour therapy were applied - one that started simultaneously with the tumour transplantation and a second one that started after the appearance of palpable tumours. The results demonstrated protective antitumour effect of erufosine, expressed by decrease of transplantability, tumour growth inhibition, suppression of metastatic activity and extension of mean survival time. The effectivity of the experimental therapy was more pronounced when it was started simultaneously with the transplantation of the tumour cells. Presented results suggest that erufosine is a promising drug candidate for treatment of haematological malignances.

Key words: alkylphosphocholines, antitumour activity, erufosine, myeloid tumour

Chemotherapy is one of the most commonly used methods for cancer treatment. Despite the undoubted advances in the treatment of oncological diseases, conventional chemotherapy has some limitations including toxicity to healthy tissues, low achievable drug concentrations at the tumour site and multidrug resistance of cancer cells. These limiting factors of the oncotherapy necessitate the development and implementation of novel therapeutics and treatment strategies.

Alkylphosphocholines (APCs) are synthetic phospholipid analogues that represent a new and promising class of anticancer agents (van Blitterswijk \& Verheij, 2008; Ríos-Marco et al., 2017). In contrast to conventional chemotherapeutic agents, which target mainly the DNA of the tumour cells, APCs primarily interfere 
with lipid metabolism and modulate lipiddependent signal transduction involved in the regulation of cellular proliferation, differentiation and apoptosis (Berger et al., 2003; Kaleagasioglu \& Berger, 2014; Ríos-Marco et al., 2017). The inhibition of phosphatidylcholine synthesis and the modulation of the proapoptotic stressactivated protein kinase (SAPK)/c-Jun Nterminal protein kinases (JNK) pathway, the prosurvival PI3K/Akt/mTOR pathway, and the mitogen-activated protein kinase (MAPK)/extracellular signal-regulated kinase (ERK) pathway have been proposed as the most important mechanisms of the antitumour effects of APCs (Martelli et al., 2010; Rudner et al. 2010; Kapoor et al., 2012).

Erufosine belongs to the third generation of APCs and is the first compound of this class that can be administered intravenously as it does not induce haemolytic and myelotoxic effects and even stimulates normal haematopoiesis (Bagley, 2011; Yosifov, 2011; Kaleagasioglu \& Berger, 2014). A number of experimental studies have shown that erufosine exerted significant in vitro antiproliferative activity in various cell lines of human haematological malignancies (Königs et al., 2010; Martelli et al., 2010) as well as solid tumours (Rudner et al., 2010; Pehlivanova et al., 2013; Ansari et al., 2018).

Graffi myeloid tumour is a transplantable, rapidly growing tumour with very aggressive behaviour. The tumour was originally induced by Graffi murine leukaemia virus in newborn hamsters (Jakimov et al., 1979) and adapted to grow in a solid form after subcutaneous inoculation of Syrian golden hamsters with tumour cells (Toshkova, 1995). This experimental tumour is a reliable model for studying the antitumour effects of natural and synthetic chemical substances, showing precise and reproducible results (Toshkova et al., 2010). The present study aims to examine the antitumour activity of erufosine on hamsters with experimental Graffi myeloid tumour by histopathological methods and evaluation of some biometric parameters of tumour growth.

\section{Experimental animals}

Thirteen Syrian Golden hamsters 2-4 months old, weighing approximately 100 $\mathrm{g}$ were purchased from the breeding base of the National Oncology Center, Sofia. For the present experiment $2 \times 10^{4}$ viable Graffi tumour cells/ $0.5 \mathrm{~mL}$ PBS per animal were transplanted subcutaneously on hamsters in the interscapular area. All experiments were conducted in accordance to the ethical standards of the institutional guidelines for care and use of laboratory animals and Regulation 20/ 01.11.2012 regarding laboratory animals and animal welfare.

\section{Antineoplastic agent}

Erufosine was kindly provided by Prof. $\mathrm{H}$. Eibl (MPI for Biophysical Chemistry, Gottingen, Germany). Erufosine was dissolved in PBS and administered subcutaneously twice a week for 4 weeks.

\section{Experimental design}

The experimental animals inoculated with tumour cells were separated in three experimental groups as followed: Group 1 untreated tumour-bearing hamsters $(\mathrm{TBH})$ (5 hamsters); Group 2 - tumour-bearing hamsters with erufosine treatment (1.5 $\mathrm{mg} / 100 \mathrm{~g}$ b.w) starting simultaneously with the tumour transplantation (4 hamsters); Group 3 - tumour-bearing hamsters with erufosine treatment $(1.5 \mathrm{mg} / 100 \mathrm{~g}$ b.w) starting after the appearance of tumours with diameter about $10 \mathrm{~mm} \mathrm{(4}$ hamsters). 


\section{Histopathology}

Tissue samples from tumours and visceral organs of experimental animals were fixed in $10 \%$ buffered formalin, dehydrated, paraffin embedded, sectioned at $5 \mu \mathrm{m}$ and stained with haematoxylin and eosin (H\&E). Histopathological lesions were identified and documented with microscope Leica DM 5000 B.

\section{Biometric parameters of the tumour growth}

Tumour transplantability (\%) was determined as a ratio between the number of hamsters with palpable tumours and the total number of hamsters in the experimental group. The tumour size was measured for each animal using a caliper and the mean tumour volume was calculated for each experimental group. The changes in the tumour volume were followed for 30 days after the tumour transplantation; Lethality (\%) was followed in dynamics between the $20^{\text {th }}$ and $50^{\text {th }}$ day after the tumour transplantation. The mean survival time was calculated for each group at the end of experiments.

\section{Statistical analysis}

The statistical significance of the differences between the control and treatment groups was evaluated by using one-way analysis of variance (ANOVA) followed by Bonferroni's post hoc test using the GraphPad Prism software package. Values $<0.05$ were considered statistically significant.

The in vivo antitumour activity of erufosine was studied in hamsters with experimental Graffi myeloid tumours. The biometric parameters transplantability, tumour volume, lethality and mean survival time were used as markers for assessment of the antineoplastic potential of the tested compound. The effect of erufosine treat- ment on the transplantabilty of Graffi tumour was followed for 20 days after the tumour transplantation (Fig. 1). The highest percentage of hamsters with palpable tumours was observed in the control Group 1. In this group, on day 8 and day 11 tumours were established in $40 \%$ and $100 \%$ of the experimental animals, respectively. In the experimental groups treated with the erufosine, starting on day 0 or day 11 , the transplantability was lower compared to the controls. On the $8^{\text {th }}$ day of the study, tumours were not found by palpation (transplantability $0 \%$ ) in Groups 2 and 3. In these experimental groups palpable tumours appeared on $11^{\text {th }}$ day in $50 \%$ of the laboratory animals. In Group 2, palpable tumours were observed in $100 \%$ of the experimental animals on day $18^{\text {th }}$ of the experiment. The transplantability observed in Group 3 reached $100 \%$ on the $15^{\text {th }}$ day. The highest protection was established in the group where treatment started simultaneously with tumour cells transplantation (Group 2).

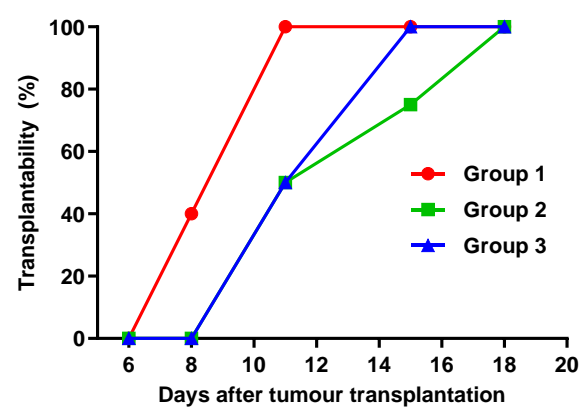

Fig. 1. Effect of erufosine treatment on the transplantability of Graffi tumour cells in hamsters. Group 1 - untreated tumour-bearing hamsters; Group 2 - tumour-bearing hamsters with erufosine treatment starting simultaneously with the tumour transplantation; Group 3 tumour-bearing hamsters with erufosine treatment starting after the appearance of palpable tumours. 
The influence of the experimental therapy on the tumour volume in Graffi myeloid tumour-bearing hamsters was monitored for 30 days. The mean tumour volume in the untreated control group of hamsters with Graffi myeloid tumour (Group 1), showed a rapid growth (Fig. 2). The rate of the increase in the tumour volume in experimental groups was noticeably reduced compared to the untreated TBH (Group 1). The mean volume of the tumours in hamsters treated with erufosine was significantly lower compared to the untreated controls (100\% inhibition of the tumour growth was established up to the $15^{\text {th }}$ day). On the $25^{\text {th }}$ day of the study the inhibition of the tumour growth was more pronounced in group 2, however on the $30^{\text {th }}$ day the tumour volume was the lowest in Group 2.

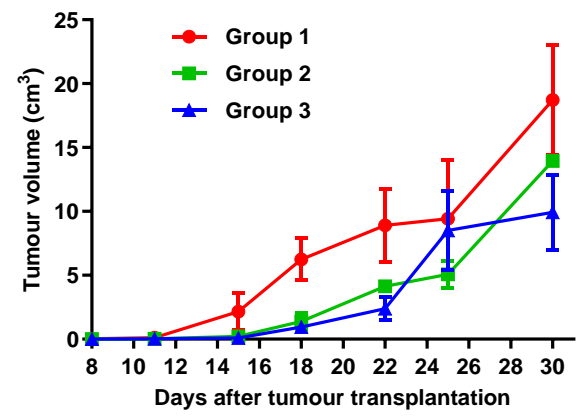

Fig. 2. Effect of erufosine treatment on the tumour volume of Graffi tumour bearing hamsters. Group 1 - untreated tumour-bearing hamsters; Group 2 - tumour-bearing hamsters with erufosine treatment starting simultaneously with the tumour transplantation; Group 3 tumour-bearing hamsters with erufosine treatment starting after the appearance of palpable tumours. Values are presented as mean \pm SEM.

The lethality of the tumour-bearing hamsters of the experimental groups treated with erufosine was found to decrease as compared to the controls (Fig. 3). At the control Group 1, 100\% lethality was found on the $30^{\text {th }}$ day after transplantation, while $50 \%$ and $0 \%$ letality was established in Groups 2 and 3, respectively. In the groups treated with erufosine, $100 \%$ lethality was reached on the $40^{\text {th }}$ and $45^{\text {th }}$ day after the transplantation.

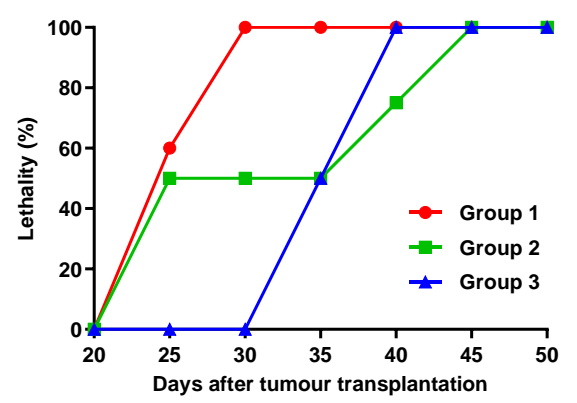

Fig. 3. Effect of erufosine treatment on the lethality of Graffi tumour- bearing hamsters. Group 1 - untreated tumour-bearing hamsters; Group 2 - tumour-bearing hamsters with erufosine treatment starting simultaneously with the tumour transplantation; Group 3 - tumourbearing hamsters with erufosine treatment starting after the appearance of palpable tumours.

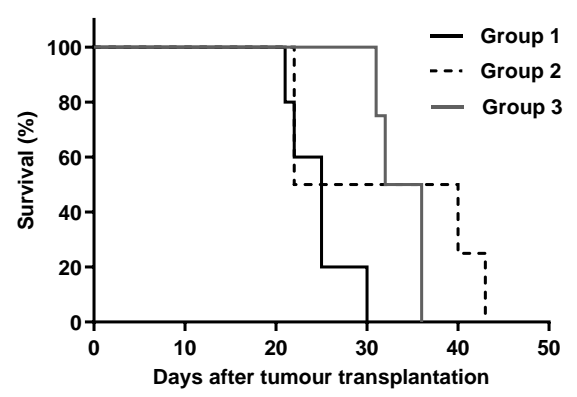

Fig. 4. Effect of erufosine treatment on the survival of Graffi tumour-bearing hamsters. Group 1 - untreated tumour-bearing hamsters; Group 2 - tumour-bearing hamsters with erufosine treatment starting simultaneously with the tumour transplantation; Group 3 - tumourbearing hamsters with erufosine treatment starting after the appearance of palpable tumours. 
The effect of the erufosine treatment on the survival of the tumour-bearing hamsters is presented on Fig. 4. The subcutaneous application of the alkylphosphocholine on Graffi myeloid tumour-bearing hamsters, starting from day 0 and day 11 (Groups 2 and 3) resulted in a prolongation of the mean survival time from $24.6 \pm 1.57$ days to $31.75 \pm 5.6$ days, $33.75 \pm 1.3$ days, respectively).

Histopathological examination of explanted tumour masses and organs with metastases from control TBH, despite of the formed capsule around the growing tumour in the locus of transplantation - a characteristic sign of this tumour, showed a high-grade malignancy appearance with undifferentiated pleomorphic anaplastic cell profile, loss of structural differentiation and morphological characteristics of maturity, anisokaryosis, anisocytosis and prominent nucleoli (Fig. 5A, B). These signs of malignancy were less distinct in the tumours or distinct metastases of erufosine-treated experimental animals, leading to slight myeloid cell differentiation of tumour cells (Fig. 5D). Histopathology of visceral organs of control TBHs revealed numerous miliary to massive metastases in the lungs (Fig 5B). Single miliary metas-

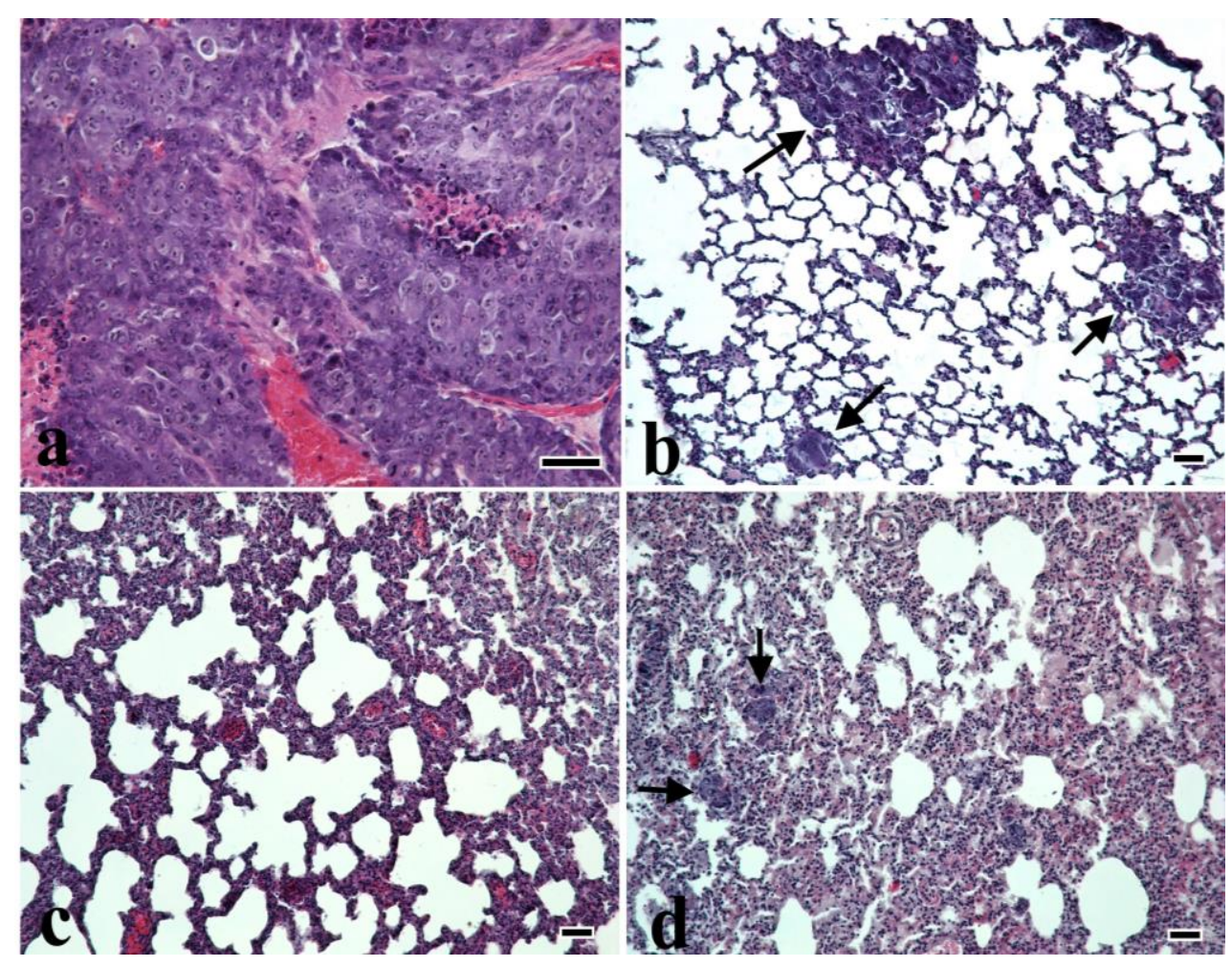

Fig. 5. Light microscopy of Graffi myeloid tumour and lungs from control and erufosine-treated tumour-bearing hamsters. A. Graffi myeloid tumour appearance presenting undifferentiated pleomorphic anaplastic cells; B. Lungs of control TBH (Group 1) with numerous miliar to massive metastases (arrows); C. Lungs of erufosine-treated TBH (Group 2) -lack of metastases; D. Lungs of erufosine-treated TBH (Group 3) with only single miliary metastases (arrows) in some animals. H\&E staining; bar $=50 \mu \mathrm{m}$. 
tases were found in the lungs of erufosinetreated hamsters of Group 3 (Fig. 5D) and no metastatic cells were identified in the lungs of TBH of Group 2 (Fig. 5Cc). Liver, spleen, kidneys and heart from all animals were free of metastases with the exception of several metastatic foci in the liver of the control hamsters.

Erufosine is a synthetic phospholipid analogue that is able to interact with the cellular membranes. Due to its chemical structure and metabolic stability, erufosine easily incorporates in the plasma membrane in substantial amounts and then spreads among intracellular membrane compartments. In the endoplasmic reticulum, erufosine inhibits the rate-limiting step of the de novo synthesis of phosphatidylcholine, which is the most abundant phospholipid in eukaryotic cellular membranes (Kaleağasıŏlu \& Berger, 2014). In addition, erufosine was found to inhibit the formation of lipid second messengers involved in the regulation of the growth, cell cycle progression, and survival of tumour cells. The interference with normal lipid metabolism and lipid-dependent signal transduction imposes the cells to severe stress and leads to initiation of apoptosis. This action is most effective in metabolically active, proliferating cells, such as cancer cells, but not in quiescent normal cells (van Blitterswijk \& Verheij, 2008). The decrease of the transpantability, reduction of the tumour volumes and extension of survival time in the erufosine-treated animals established in our study could be explained with the affected lipid metabolism of the tumour cells.

Previous studies have shown that erufosine has a pronounced in vitro antiproliferative activity and ability to induce apoptosis, autophagy and cell cycle arrest in cell lines with various tissue origin including mammary adenocarcinoma, pros- tate carcinoma (Rudner, 2010), colorectal carcinoma (Kaleağasığlu \& Berger, 2014), pancreatic carcinoma (Bagley et al., 2011), oral squamous cell carcinoma (Kapoor et al., 2012; Ansari et al., 2018), glioblastoma (Rübel et al., 2006), chronic lymphocytic leukaemia (Königs et al., 2010) and acute myeloid leukaemia (Fiegl et al., 2008). In vivo studies have also indicated antitumour effects of erufosine in chemically induced mammary carcinoma (Dineva et al., 2012) and glioblastoma xenograft tumours (Henke et al., 2012). The results of the present study complement and confirm previously published data and indicate that erufosine has a marked antitumour effect on virus-induced transplantable myeloid tumours in hamsters.

In conclusion, the novel alkylphosphocholine erufosine exerted a significant antitumour effect on Graffi myeloid tumour, expressed by decrease of transplantability, tumour growth inhibition, suppression of metastatic activity and extension of mean survival time. Presented results suggested erufosine as a promising therapeutic agent for anticancer treatment.

\section{ACKNOWLEDGEMENTS}

This work was supported by Grant DFNI BO2/5-2014 from Bulgarian National Science Fund of Ministry of Education and Science.

\section{REFERENCES}

Ansari, S. S., A. K. Sharma, H. Soni, D. M. Ali, B. Tews, R. König, H. Eibl \& M. R. Berger, 2018. Induction of ER and mitochondrial stress by the alkylphosphocholine erufosine in oral squamous cell carcinoma cells. Cell Death \& Disease, 9, 296.

Bagley, R. G., L. Kurtzberg, C. Rouleau, M. Yao \& B. A. Teicher, 2011. Erufosine, an 
alkylphosphocholine, with differential toxicity to human cancer cells and bone marrow cells. Cancer Chemotherapy \& Pharmacology, 68, 1537-1546.

Berger, M., I. Tsoneva, S. Konstantinov \& H. Eibl, 2003. Induction of apoptosis by erucylphospho-N, N, N-trimethylammonium is associated with changes in signal molecule expression and location. Annals of the New York Academy of Sciences, 1010, 307-310.

Dineva, I. K., M. M. Zaharieva, S. M. Konstantinov, H. Eibl \& M. R. Berger, 2012. Erufosine suppresses breast cancer in vitro and in vivo for its activity on PI3K, c-Raf and Akt proteins. Journal of Cancer Research \& Clinical Oncology, 138, 1909-1917.

Fiegl, M., L. H. Lindner, M. Juergens, H. Eibl, W. Hiddemann \& J. Braess, 2008. Erufosine, a novel alkylphosphocholine, in acute myeloid leukemia: Single activity and combination with other antileukemic drugs. Cancer Chemotherapy \& Pharmacology, 62, 321-329.

Henke, G., V. Meier, L. H. Lindner, H. Eibl, M. Bamberg, C. Belka, W. Budach \& V. Jendrossek, 2012. Effects of ionizing radiation in combination with Erufosine on T98G glioblastoma xenograft tumours: a study in NMRI nu/nu mice. Radiation Oncology, 7,172.

Jakimov, M., Z. Mladenov, A. Konstantinov \& I. Yanchev, 1979. Transplantable myeloid tumor in hamsters (MTH) induced by Graffi virus. General \& Comparative Pathology, 6, 24-35.

Kaleagasioglu, F. \& M. Berger, 2014. Alkylphosphocholines and the current anticancer profile of erufosine. International Journal of Molecular Medicine, 34, S34.

Kaleağası̆ğlu, F. \& M. R. Berger, 2014. Differential effects of erufosine on proliferation, wound healing and apoptosis in colorectal cancer cell lines. Oncology Reports, 31, 1407-1416.

Kapoor, V., M. Zaharieva, S. Das \& M. Berger, 2012. Erufosine simultaneously induces apoptosis and autophagy by modulating the Akt-mTOR signaling pathway in oral squamous cell carcinoma. Cancer Letters, 319, 39-48.

Königs S., C. Pallascha \& L. Lindnerb, 2010. Erufosine, a novel alkylphosphocholine, induces apoptosis in CLL through a caspase-dependent pathway. Leukemia Research, 34, 1064-1069.

Martelli A., V. Papa \& P. Tazzari, 2010. Erucylphosphohomocholine, the first intravenously applicable alkylphosphocholine, is cytotoxic to acute myelogenous leukemia cells through JNK- and PP2Adependent mechanisms. Leukemia, 24, 687-698.

Pehlivanova, V., V. Uzunova, I. Tsoneva, M. R. Berger, I. Ugrinova \& R. Tzoneva, 2013. Effect of erufosine on the reorganization of cytoskeleton and cell death in adherent tumor and non-tumorigenic cells. Biotechnology \& Biotechnological Equipment, 27, 3695-3699.

Ríos-Marco, P., C. Marco, X. Gálvez, J. M. Jiménez-López \& M. P. Carrasco, 2017. Alkylphospholipids: An update on molecular mechanisms and clinical relevance. Biochimica et Biophysica Acta. Biomembranes, 1859, Part B, 1657-1667.

Rübel, A., R. Handrick, L. H. Lindner, M. Steiger, H. Eibl, W. Budach, C. Belka \& V. Jendrossek, 2006. The membrane targeted apoptosis modulators erucylphosphocholine and erucylphosphohomocholine increase the radiation response of human glioblastoma cell lines in vitro. Radiation Oncology, 1 , 6.

Rudner, J., C. Ruiner, R. Handrick, H. Eibl, C. Belka \& V. Jendrossek, 2010. The Aktinhibitor erufosine induces apoptotic cell death in prostate cancer cells and increases the short term effects of ionizing radiation. Radiation Oncology, 5, 108.

Toshkova, R., 1995. Attempts for immunomodulation in hamsters with transplanted myeloid tumor, previously induced by 
Graffi virus. PhD Thesis, Sofia, Bulgaria, p.168.

Toshkova, R., N. Manolova, E. Gardeva, M. Ignatova, L. Yossifova, I. Rashkov \& M. Alexandrov, 2010. Antitumor activity of quaternized chitosan-based electrospun implants against Graffi myeloid tumor. International Journal of Pharmaceutics, 400, 221-233.

van Blitterswijk, W. \& M. Verheij, 2008. Anticancer alkylphospholipids: Mechanisms of action, cellular sensitivity and resistance, and clinical prospects. Current Pharmaceutical Design, 14, 2061-2074.

Yosifov, D. Y., P. T. Todorov, M. M. Zaharieva, K. D. Georgiev, B. A. Pilicheva, S. M. Konstantinov \& M. R. Berger, 2011. Erucylphospho-N, N, N-trimethylpropylammonium (erufosine) is a potential antimyeloma drug devoid of myelotoxicity.
Cancer Chemotherapy \& Pharmacology, 67, 13-25.

Paper received 28.07.2019; accepted for publication 31.10.2019

\section{Correspondence:}

Ani K. Georgieva

Institute of Experimental Morphology,

Pathology and Anthropology with Museum,

Bulgarian Academy of Sciences,

Sofia, Bulgaria

e-mail: georgieva_any@abv.bg 